\title{
Uji Aktivitas Antioksidan Ektrak Ethanol Daun Family Solanum Menggunakan Metode Reduksi Radikal Bebas DPPH
}

\author{
Anif Nur Artanti ${ }^{*}$ dan Renita Lisnasari ${ }^{1}$ \\ ${ }^{1}$ Program Studi Farmasi, Fakultas Matematika dan Ilmu Pengetahuan Alam, Universitas Sebelas Maret \\ *email korespondensi : anif.apt@ staff.uns.ac.id
}

\begin{abstract}
Abstrak. Antioksidan adalah zat yang menghambat atau mencegah kerusakan sel akibat oksidasi radikal bebas. Buah yang berasal dari tanaman yang termasuk dalam Solanum Family memiliki potensi sebagai antioksidan, namun aktivitas antioksidan pada bagian daun tidak diketahui. Penelitian ini bertujuan untuk mengetahui keragaman aktivitas antioksidan pada daun Solanum Family yaitu daun ciplukan (Physalisan gulata L.), daun takokak (Solanumtorvum Swartz) dan daun tomat (Solanum lycopersicum L.). Parameter aktivitas antioksidan diukur dengan nilai IC $\mathrm{I}_{50}$. Metode Penelitian ini menggunakan ekstrak etanol daun ciplukan, daun takokak dan daun tomat diekstraksi dengan etanol $70 \%$ dengan metode perkolasi. Pengujian aktivitas antioksidan dengan DPPH (1,1-Diphenyl-2-picrylhydrazyl). Identifikasi kandungan fitokimia dan uji aktivitas antioksidan secara kualitatif dengan kromatografi lapis tipis (KLT). Aktivitas antioksidan uji kuantitatif dengan spektrofotometri UV-Vis pada panjang gelombang $515 \mathrm{~nm}$ dengan perbandingan vitamin C. Hasil penelitian menunjukkan bahwa daun Solanum Family mengandung flavonoid, saponin, dan polifenol. Nilai $\mathrm{IC}_{50}$ daun ciplukan adalah $59,73 \pm 0,24$ ppm (aktivitas antioksidan kuat) daun tomat 80,79 \pm 0,27 ppm (aktivitas antioksidan kuat), daun takokak 107,42 \pm 0,43 ppm (aktivitas antioksidan sedang), injeksi vitamin C sebagai kontrol positif meiliki nilai $\mathrm{IC}_{50} 2,89 \pm 0,20 \mathrm{ppm}$ (aktivitas antioksidan sangat kuat). Hasil penelitian menunjukkan bahwa ekstrak etanol dari daun Solanum Family menghasilkan aktivitas antioksidan. Penelitian farmakologi lebih lanjut dilakukan untuk mengevaluasi aktivitas antioksidan daun Solanum Family.
\end{abstract}

Kata kunci: Antioksidan; Ekstrak Etanol; Solanum Family

Abstract. Antioxidant activity test of ethanolic extract from solanum family leaves using free radicals dpph reduction. Antioxidants are substances that inhibit or prevent damage or destruction due to the oxidation of free radicals. Solanum family's fruit has potential as antioxidant, but the activity has not been known yet. This research aims to determine the antioxidant activity on solanum family's leaves i.e ciplukan leaves (Physalisan gulata L.), takokak leaves (Solanumtorvum Swartz) and tomato leaves (Solanum lycopersicum L.). The parameter of antioxidant activity is measured by $\mathrm{IC}_{50}$ value. This study is an experimental research laboratory. The ethanol extract of ciplukan leaves, takokak leaves and tomato leaves was extracted with $70 \%$ ethanol using percolation methode. Testing of antioxidant activity with DPPH (1,1-Diphenyl-2-picrylhydrazyl). Phytochemical content and antioxidant activity were qualitatively identified by thin layer chromatography (TLC). Quantitative test antioxidant activity with UV-Vis spectrophotometry at a wavelength of $515 \mathrm{~nm}$ with a comparison of vitamin C. The results showed that solanum family's leaves containing flavonoids, saponins, and 
polyphenols. The value $\mathrm{IC}_{50}$ of ciplukan leaves is $59,73 \pm 0,24 \mathrm{ppm}$ (strong antioxidant activity, tomato leaves is $80.79 \pm 0,27 \mathrm{ppm}$ (strong antioxidant activity), takokak leaves is $107,42 \pm$ $0,43 \mathrm{ppm}$ (medium antioxidant activity), vitamin $\mathrm{C}$ injection as positive control $\mathrm{IC}_{50}$ value is 2,89 $\pm 0,20 \mathrm{ppm}$ (very strong antioxidant activity). The result demonstrated that the ethanolic extract from solanum family's leaves exert potent antioxidant activity. Further pharmalogical investigation needs to be carried out to evaluate the antioxidant of Solanum family's leaves.

Keywords: Antioxidants; Ethanol Extracts; Solanum Family

\section{Pendahuluan}

Pesatnya perkembangan ilmu pengetahuan dan teknologi serta perubahan pola hidup masyarakat menjadi hidup yang praktis, dapat memicu terbentuknya radikal bebas. Radikal bebas dapat masuk dan terbentuk kedalam tubuh melalui pernafasan, kondisi lingkungan yang tidak sehat, dan makanan berlemak (Kumalaningsih, 2006). Radikal bebas dapat bereaksi dengan protein, asam-asam lemak, bahkan DNA sehingga dapat menimbulkan penyakit, kerusakan pada sel dan jaringan yang merupakan akar dari sebagian besar penyakit disebabkan oleh radikal bebas (Kumalaningsih, 2006). Manusia dapat memproduksi senyawa-senyawa yang dapat berperan aktif dalam menanggulangi radikal bebas, seperti enzim superoksida dismutase dan glutathione namun jumlahnya sering sekali tidak mencukupi. Oleh sebab itu dibutuhkan asupan makanan yang banyak mengandung antioksidan seperti vitamin $\mathrm{C}$, E, betakaroten, maupun antioksidan sehingga dapat melindungi dari serangan radikal bebas. Sumber antioksidan alami ini dapat diperoleh dari buah-buahan dan sayur-sayuran (Kumalaningsih, 2006). Ekstrak etanolik ciplukan mempunyai efek sitotoksik terhadap sel myeloma dengan nilai $\mathrm{IC}_{50}$ 70,92 g/mL (Diah, 2007). Aktivitas antioksidan dari ekstrak buah tomat dalam metanol memiliki nilai IC $_{50}$ yaitu kekuatan antioksidan untuk menonaktifkan radikal bebas sebanyak 50\% adalah sebanyak 50\% adalah sebesar 44,06 $\mu \mathrm{g} / \mathrm{mL}$ lebih rendah dari vitamin $\mathrm{C}$ sebesar 3,63 $\mu \mathrm{g} / \mathrm{mL}$ (Fatricia, 2012). Buah takokak mengandung senyawa flavonoid, saponin, kuinon dan steroid (Laili dan Tita, 2014). Untuk menguji adanya aktivitas antioksidan dapat menggunakan metode DPPH. Pengamatan terhadap penangkapan radikal DPPH dapat dilakukan dengan mengamati penurunan absorbansi. Hal ini dapat terjadi oleh karena adanya reduksi radikal oleh antioksidan atau bereaksi dengan senyawa radikal lainnya (Yu dkk, 2002). Penelitian yang dilakukan tentang uji aktivitas antioksidan pada ciplukan, takokak dan tomat yang selama ini difokuskan kepada bagian buah. Upaya pemanfaatan daun belum digunakan secara maksimal oleh masyarakat. Senyawa kimia khususnya flavonoid sebagai antioksidan yang terkandung dalam bagian buah dapat tersebar pula di bagian tanaman lainnya, yaitu pada bagian daun. 


\section{Bahan dan Metode}

\subsection{Preparasi Sampel}

Pembuatan ektrak daun masing-masing dilakukan dengan cara ektraksi metode perkolasi menggunakan etanol 70\% selama 3 hari dengan perbandingan pelarut:simplisia (3:1). Pelarut terus ditambahkan dan dijaga agar simplisia tidak kekeringan dan hingga tetesan perkolasi berwarna bening. Ekstrak cair yang diperoleh dipekatkan menggunakan waterbatch hingga diperoleh ekstrak kental.

\subsection{Skrining fitokimia}

Skrining Fitokimia dilakukan menggunakan Kromatografi Lapis Tipis (KLT) dengan fase diam silika gel GF 254 yang telah diaktifkan dan fase gerak setiap uji. Ekstrak ditotolkan pada batas bawah fase diam dan dimasukkan ke dalam chamber yang berisi fase gerak yang telah dijenuhkan. Ditunggu hingga totolan ekstrak terelusi oleh fase gerak hingga batas atas lempeng dikeringkan kemudian dideteksi penampak bercak dengan sinar UV $254 \mathrm{~nm}$ dan $366 \mathrm{~nm}$.

\subsection{Uji aktifitas antioksidan}

\subsubsection{Pembuatan larutan DPPH 0,004\%}

Ditimbang 6 mg serbuk DPPH, diencerkan dengan metanol p.a dalam labu ukur $150 \mathrm{~mL}$, dibuat dengan konsentrasi 40 ppm.

\subsubsection{Skrining panjang gelombang maksimal}

Larutan DPPH 0,004\% divortex lalu dibiarkan 30 menit, diukur pada spektrum uv-vis, sehingga diperoleh panjang gelombang maksimal dan nilai absorbansinya.

\subsubsection{Uji aktivitas antioksidan secara kuantitatif}

Larutan kontrol positif : vitamin $\mathrm{C}$ dibuat larutan induk $10 \mathrm{ppm}$ dan diencerkan hingga diperoleh larutan seri 2, 4, 6, 8 dan 10 ppm. Larutan sampel uji berupa ekstrak dibuat larutan induk 120 ppm dan diencerkan hingga diperoleh larutan seri 10;30;60;90;120 ppm.

\subsection{Pengukuran absorbansi sampel}

Masing-masing larutan uji dan vitamin $\mathrm{C}$ dipipet $2 \mathrm{~mL}$, ditambahkan $2 \mathrm{~mL}$ DPPH 0,004\% divortex dan dibiarkan di suhu kamar selama 30 menit, diukur serapannya pada panjang gelombang optimumnya (Hanani dkk, 2005). Setiap konsentrasi sampel dilakukan replikasi 2x.

\subsection{Analisa data}

Perhitungan persentase aktivitas antioksidan dapat menggunakan rumus: 
$\%$ aktivitas antioksidan $=\frac{a b s D P P H \text { kontrol-abs } D P P H}{a i s a} \times 100 \%$

(Sari, 2012)

Setelah didapatkan \%aktivitas antioksidan kemudian dibuat grafik antara konsentrasi dengan rata-rata $\%$ aktivitas antioksidan sehingga didapatkan nilai $\mathrm{y}=\mathrm{bx}+\mathrm{a}$, kemudian di hitung nilai $\mathrm{IC}_{50}(\mathrm{x})$ dengan rumus sebagai berikut $: \frac{50-a}{b}$ lalu dibandingkan dengan hasil SPSS uji probit.

\section{Hasil dan Pembahasan}

Pada penelitian ini, skrining fitokimia dilakukan secara kualitatif dengan uji Kromatografi Lapis Tipis (KLT). Pemisahan campuran didasarkan atas perbedaan distribusi dari komponen-komponen campuran tersebut diantara dua fase, yaitu fase diam dan fase gerak. Fase diam yang digunakan adalah lempeng silika gel $F_{254}$. Dalam kromatografi lapis tipis pemilihan sistem pelarut yang dipakai didasarkan atas prinsip like dissolves like. Pengujian flavonoid dilakukan dengan fase diam silika gel $\mathrm{GF}_{254}$ dan fase gerak berupa metanol : kloroform (9:7). Hasil positif ditunjukkan dengan warna spot coklat pada nilai hRf 80 (Fajar dkk, 2011). Pengujian saponin dilakukan dengan fase diam silika gel $\mathrm{GF}_{254}$ dan fase gerak berupa metanol : kloroform (5:95). Hasil positif ditunjukkan dengan warna spot biru-biru violet dengan nilai hRf 32 (Cut dkk, 2009). Pengujian Tanin dilakukan dengan fase diam silika gel $\mathrm{GF}_{254}$ dan fase gerak berupa kloroform : etil asetat : asam formiat (0,5:9:0,5). Hasil positif ditunjukkan dengan nilai hRf 45 (Widyowati dan Rohman, 2010). Pengujian polifenol dilakukan dengan fase diam silika gel $\mathrm{GF}_{254}$ dan fase gerak berupa kloroform : metanol (9:1). Hasil positif ditunjukkan dengan warna spot hijau klabu dan nilai hRf 21 (Sulistyani dan Kusuma, 2012).
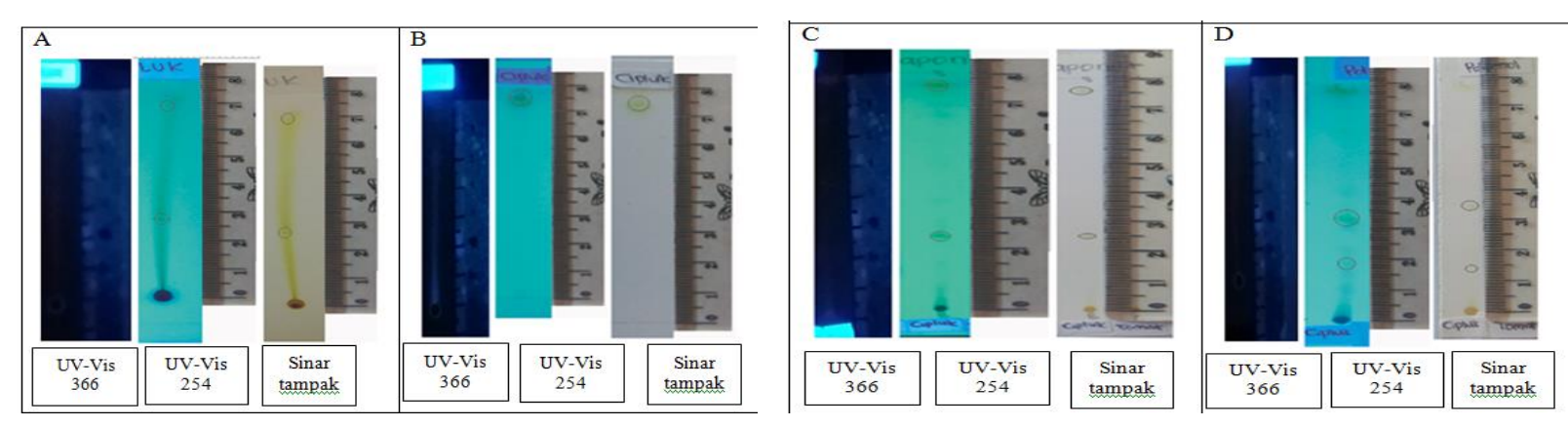

Gambar 1. Hasil uji kromatografi lapis tipis (KLT) daun ciplukan (Physalis angulata L) untuk identifikasi A. Flavonoid, B. Tanin, C. Saponin, D. Polifenol di bawah UV 366, 254 dan sinar tampak.

Hasil nilai Rf ketiga ekstrak menunjukan bahwa semua ekstrak daun positif mengandung senyawa flavonoid, saponin, polifenol dan tidak memiliki senyawa tanin. Pengujian antioksidan 
secara kuantitatif dilakukan dengan metode DPPH. Metode pengujian dilakukan dengan metode uji DPPH menggunakan 2,2 difenil-1-pikrilhidrazil yang merupakan sumber radikal bebas. Larutan DPPH dibuat dengan konsentrasi 40 ppm atau 0,004\%. Diperoleh lamda maksimal pada konsentrasi 40 ppm sebesar 515 dengan absorbansi 0,7612 .
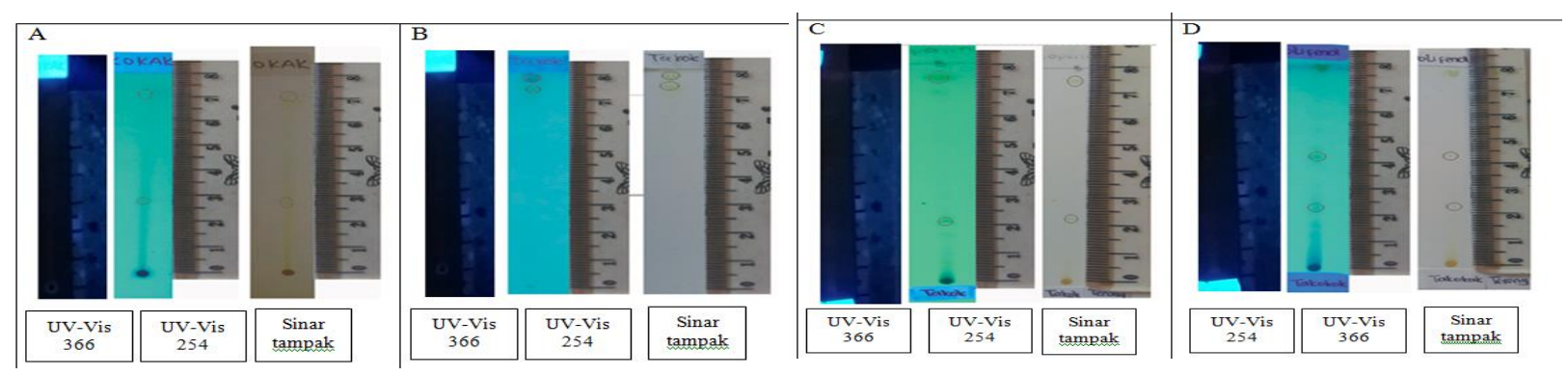

Gambar 2. Hasil uji kromatografi lapis tipis (KLT) daun takokak (Solanum torvum Swartz) A. Flavonoid, B. Tanin, C. Saponin, D. Polifenol di bawah UV 366, 254 dan sinar tampak.
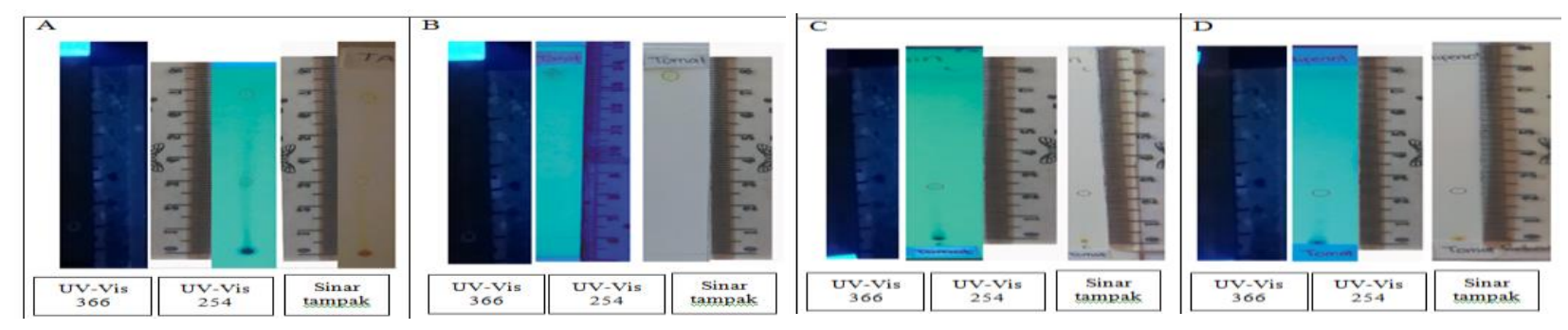

Gambar 3. Hasil uji kromatografi lapis tipis (KLT) daun tomat (Solanum lycopersicum L) untuk identifikasi A. Flavonoid, B. Tanin, C. Saponin, D. Polifenol di bawah UV 366, 254 dan sinar tampak.

Tabel 1. Hasil uji kromatografi lapis tipis (KLT) dan perhitungan Rf daun ciplukan, daun takokak dan daun tomat

\begin{tabular}{clcccc}
\hline Nama Daun & Senyawa & Hasil & Literatur & Keterangan & Kesimpulan \\
\hline Daun & Flavonoid & $0,33 \& 0,86$ & 0,8 & Fajar dkk, 2011 & $(+)$ \\
Ciplukan & Tanin & 0,93 & 0,45 & Widyowati \& Abdul, 2010 & $(-)$ \\
& Saponin & $0,30 \& 0,95$ & 0,32 & Cut dkk,2009 & $(+)$ \\
& Polifenol & $0,23 \& 0,42$ & 0,21 & Sulistyani \& Kusuma, 2012 & $(+)$ \\
\hline Daun & Flavonoid & $0,33 \& 0,88$ & 0,8 & Fajar dkk, 2011 & $(+)$ \\
Takokak & Tanin & $0,92 \& 0,98$ & 0,45 & Widyowati \& Abdul, 2010 & $(-)$ \\
& Saponin & $0,26 \& 0,93$ & 0,32 & Cut dkk,2009 & $(+)$ \\
& Polifenol & $0,28 \& 0,53$ & 0,21 & Sulistyani \& Kusuma, 2012 & $(+)$ \\
\hline \multirow{2}{*}{ Daun } & Flavonoid & $0,37 \& 0,85$ & 0,8 & Fajar dkk, 2011 & $(+)$ \\
Tomat & Tanin & 0,96 & 0,45 & Widyowati \& Abdel, 2010 & $(-)$ \\
& Saponin & 0,28 & 0,32 & Cut dkk, 20009 & $(+)$ \\
& Polifenol & 0,27 & 0,21 & Sulistyani \& Kusuma, 2010 & $(+)$ \\
\hline
\end{tabular}

Untuk menganalisis apakah semua ekstrak mempunyai aktivitas antioksidan, digunakan persamaan regresi linier untuk mencari nilai Inhibitory Concentration (50\%) IC $_{50}$. Besarnya 
aktivitas penangkap radikal bebas dinyatakan dengan $\mathrm{IC}_{50}$ yaitu besarnya konsentrasi larutan uji yang mampu menurunkan 50\% absorbansi DPPH. Sampel dinyatakan sebagai antioksidan sangat kuat jika nilai $\mathrm{IC}_{50}<50$ ppm, kuat jika nilai $\mathrm{IC}_{50}$ 50-100 ppm, sedang jika nilai $\mathrm{IC}_{50}$ 100-150 ppm, lemah jika nilai IC 50 151-200 ppm, dan dinyatakan tidak aktif jika mempunyai nilai IC $_{50}$ >200 ppm (Nicoli dkk,1999). Semakin tinggi konsentrasi ekstrak, semakin besar pula aktivitas antioksidan yang dihasilkan.

Tabel 2. Hasil uji aktivitas antioksidan dan perhitungan nilai $\%$ aktivitas antioksidan daun ciplukan, daun takokak dan daun tomat

\begin{tabular}{|c|c|c|c|}
\hline No & Sampel & Konsentrasi (ppm) & \%Aktivitas antioksidan \\
\hline \multirow[t]{5}{*}{1} & Daun ciplukan & 10 & 11,76 \\
\hline & & 30 & 31,38 \\
\hline & & 60 & 54,85 \\
\hline & & 90 & 71,66 \\
\hline & & 120 & 73,37 \\
\hline \multirow[t]{5}{*}{2} & Daun tomat & 10 & 8,39 \\
\hline & & 30 & 25,99 \\
\hline & & 60 & 42,45 \\
\hline & & 90 & 58,74 \\
\hline & & 120 & 65,66 \\
\hline \multirow[t]{5}{*}{3} & Daun takokak & 10 & 8,28 \\
\hline & & 30 & $18=11$ \\
\hline & & 60 & 38,12 \\
\hline & & 90 & 44,91 \\
\hline & & 120 & 51,04 \\
\hline \multirow[t]{4}{*}{4} & Vitamin $\mathrm{C}$ & 2 & 48,54 \\
\hline & & 4 & 52,18 \\
\hline & & 6 & 61,07 \\
\hline & & 8 & 73,41 \\
\hline
\end{tabular}

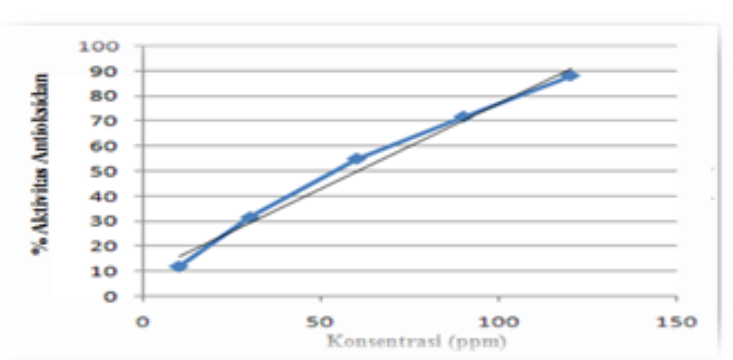

(A)

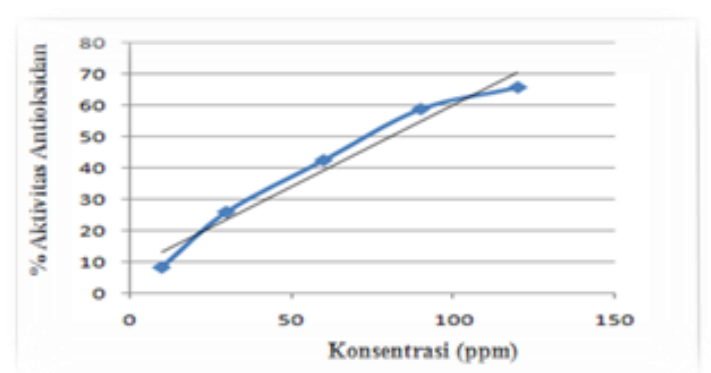

(C)

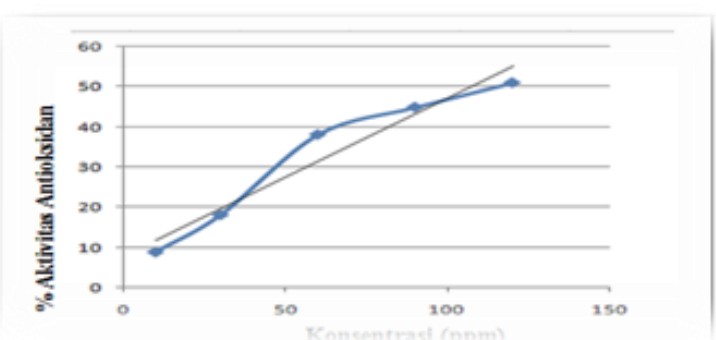

(B)

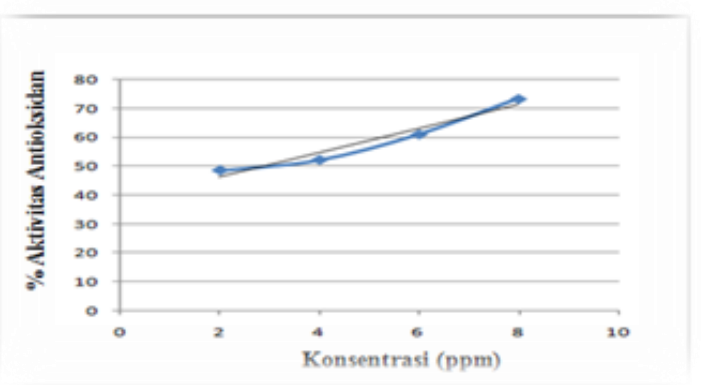

(D)

Gambar 4. Grafik hasil uji aktivitas antioksidan (A) daun ciplukan (Physalis angulata L), (B) daun takokak (Solanumtorvum Swartz) (C) daun tomat (Solanum lycopersicum L.) (D) vitamin $\mathrm{C}$ 
Semakin kecil nilai IC50 menunjukkan semakin tinggi aktivitas antioksidannya (Molyneux, 2004). Berdasarkan hasil analisis, ekstrak etanol daun ciplukan (Physalis angulata L), daun takokak (Solanum torvum Swartz) dan daun tomat (Solanum lycopersicum L) memiliki aktivitas antioksidan. Daun ciplukan dan daun tomat merupakan antioksidan kuat (50-100 ppm) dengan nilai IC $_{50}$ masing-masing 64,78 ppm dan 81,75 ppm, sedangkan daun takokak merupakan antioksidan sedang (100-150 ppm) dengan nilai $\mathrm{IC}_{50}$ 105,80 ppm, sehingga diantara ketiga sampel daun yang memiliki antioksidan paling baik adalah daun ciplukan dengan nilai $\mathrm{IC}_{50} 64,78$ ppm. Vitamin C yang digunakan sebagai pembanding, merupakan antioksidan yang sangat kuat (<50 ppm) dengan nilai $\mathrm{IC}_{50} 2,89$ ppm.

Tabel 3. Hasil uji aktivitas antioksidan dan perhitungan nilai Inhibitory concentration 50\% (IC50) daun ciplukan, daun takokak dan daun tomat

\begin{tabular}{lccc}
\hline No & Sampel & $\begin{array}{c}\boldsymbol{I C}_{\mathbf{5 0}} \text { SPSS } \\
\text { Probit (ppm) }\end{array}$ & $\begin{array}{c}\text { Rentang } \\
\text { (ppm) }\end{array}$ \\
\hline 1 & $\begin{array}{c}\text { Ekstrak daun } \\
\text { ciplukan } \\
\text { Ekstrak daun } \\
\text { Tomat }\end{array}$ & 64,78 & $49,36-80,31$ \\
3 & 81,75 & $73,57-90,52$ \\
4 & $\begin{array}{c}\text { Ekstrak daun } \\
\text { Takokak }\end{array}$ & 105,80 & $94,68-118,63$ \\
& Vitamin C & 3,22 & $1,60-4,5$ \\
\hline
\end{tabular}

\section{Kesimpulan}

Ekstrak etanol daun family Solanum positif mengandung senyawa flavonoid, saponin, polifenol dan tidak memiliki senyawa tanin. Ekstrak etanol daun ciplukan ( memiliki aktivitas antioksidan kuat dengan nilai $\mathrm{IC}_{50}$ yaitu $64,78 \pm 0.24 \mathrm{ppm}$. Ekstrak etanol daun tomat (Solanum lycopersicum L) memiliki aktivitas antioksidan kuat dengan nilai $\mathrm{IC}_{50}$ yaitu $81,78 \pm 0.27$ ppm. Ekstrak etanol daun takokak (Solanum torvum Swartz) memiliki aktivitas antioksidan sedang dengan nilai $\mathrm{IC}_{50}$ yaitu $105,80 \pm 0,43 \mathrm{ppm}$.

\section{Daftar Pustaka}

Cut, M.N., Faizatun, A., dan Sumantri., 2009, Uji Aktivitas Antibakteri Ekstrak Etanol Daun Jarak Pagar (Jatropha curcas L) Terhadap Bakteri Staphylococcus aureus ATCC 25923, Escherichia coli ATCC 25922, Dan Salmonella typhi ATCC 1408, Jurnal Ilmu Pertanian, $5(2): 35$.

Departemen Kesehatan Republik Indonesia., 2000, Parameter Standar Umum Ekstrak Tumbuhan Obat, Cetakan Pertama, Departeman Kesehatan Republik Indonesia, Direktorat 
Jenderal Pengawasan Obat dan Makanan, Direktorat Pengawasan Obat Tradisional, Jakarta.

Diah, I., 2007, Efek Sitotoksik dan Kinetika Proliferasi Ekstrak Etanolik Tanaman Ceplukan (Physalis angulata L) terhadap Sel Myeloma, Skripsi, Fakultas Farmasi UMS, Surakarta.

Fajar, MD., Esti, R.S. dan Rismawati, E., 2011, Pengaruh Perbedaan Metode Ekstraksi Terhadap Aktivitas Antioksidan Ekstrak Etanol Daun Jambu Biji (Psidium guajava L) Berdaging Buah Putih, Prosiding SnaPP2011 Sains, Teknologi, dan Kesehatan, 2:1.

Fatricia, I., Winarni, D., Pidada, R., 2012, Pengaruh Pemberian Tomat (Solanum lycopersicum L) terhadap Histology Kelenjar Mammae Mencit yang Diinduksi 7,12Dimetilbenz(a)antrasena (DMBA), Jurnal Matematika Dan Ilmu Pengetahuan, Vol.15, Universitas Airlangga, Surabaya.

Kumalaningsih, S., 2006, Antioksidan Alami-Penangkal Radikal Bebas, Sumber, Manfaat, Cara Penyediaan dan Pengolah, Trubus Agrisarana, Surabaya.

Laili, N.D.H., Tita, N., 2014, Penelusuran Potensi Antifertilitas Buah Takokak (Solanum torvum Swartz) Melalui Skrining Fitokimia Dan Pengaruhnya Terhadap Siklus Estrus Tikus Putih (Rattus novergicus), Jurnal Kesehatan, Stikes Bakti Tunas Husada, Tasikmalaya.

Molyneux, P., 2004, The Use of The Stable Free Radical Diphenylpicryl-hydrazyl (DPPH) for Estimating Antioxidant Activity, J. Sci.Technol, 26(2) : 211-219.

Sulistyani, N. dan Kusuma, L.W., 2012, Uji Aktivitas Antibakteri Ekstrak Etil Asetat Daun Binahong (Anredera scandens (L)Moq.)Terhadap Shigella flexneri Beserta Profil Kromatografi Lapis Tipis, Jurnal Ilmiah Kefarmasian, 2:1.

Widyowati, R., dan Rohman, A., 2010, Kandungan Kimia dan Aktivitas Antimikroba Ekstrak Garcinia celebica I Terhadap Staphylococus aureus, Shigella dysenteriae dan Candida albicans, Majalah Farmasi Airlangga, 8:2.

Yu, L.L., Scott, H., Jonathan, P., Mary, H., John, W., Ming, Q., 2002, Free Radical Scavenging Properties of Wheat Extracts, Journal Agriculture and Chemistry, 50(6) : 1619-1624 